\title{
Guyana should Re-Evaluate its WTO Membership
}

\section{Frederic Fielder}

Department of Law, Graduate School of Zhejiang University, China

\begin{abstract}
Not all countries that entered the World Trade Organization (WTO) were fortunate to see an increase in economic growth as a result thereof, hence my urging for Guyana to re-evaluate its WTO membership and give serious consideration to exiting. There should be a critical look at the reasons why underdeveloped countries joined and how they gained or lost and also, carefully examine the rules and trading practices of the more developed countries. The WTO has stagnated industrial and economic growth in Guyana by limiting its ability to regulate the inflow of cheap goods from more developed manufacturing economies such as the US and the EU. It is better for countries such as Guyana to focus more on Bilateral Investment Treaties (BITs) and treaties with individual trading blocs, such as CARICOM, with the aim of lowering the cost of exporting its manufactured products.
\end{abstract}

Keywords: WTO; Unemployment; Economy; Agricultural policy

\section{Guyana should Re-Evaluate its WTO Membership}

The WTO started, officially, enrolling members on January 1, 1995, and within that year signed $66 \%$ of its current members. ${ }^{1}$ What is striking about this percentage is that 58 of those countries, approximately $53 \%$, are considered underdeveloped or developing nations. The countries from the Caribbean, Latin America, and Africa, which make up the majority of the first year signatories, have shown minimal economic improvement since joining the WTO [1]. Approximately $6 \%$ of these countries have improved economically, but their meager economic progress cannot be linked directly to joining the WTO in the same way China's economic progress can be directly linked to its ascension to the WTO. Of the 76 founding members, more than $65 \%$ of them are still underdeveloped countries.

One of the key hindrances to Guyana becoming a successful member of the WTO was the trade in illegal drugs, instead of goods and commodities, between neighboring WTO members. At the time Guyana joined the WTO there was a plan in place by the Government to establish a viable manufacturing economy, instead, like most post-colonial countries the economy depended on the products manufactured and exported during the colonial days. What made things worse was that the mode of production was not modernized, making export cost of products such as sugar and bauxite uncompetitive with Europe's and other developed countries' modern practices.

The key factor that links these countries and their economic stagnation is political corruption, resulting in a weak manufacturing sector [2]. Take Guyana for example, during the period from 1995 to 2005 the country experienced a spike of $46 \%$ in drug-related crimes, many of the crimes were as a result of drugs being imported to Guyana from Columbia, Brazil and Venezuela. Due to the stagnation of the economy, Guyana was ripe for the drug trade to take root, and quickly it became the largest trans-shipment point for illegal drugs in South America. By the year 2000, the illegal drug market was estimated at 3.3 billion dollars, $4 \%$ of the region's gross domestic product, with Guyana being at the center to the drug trade for the region. ${ }^{2}$ The number is much larger when you factor in the numerous businesses that were established to launder the illegal money generated by the drug trade. Between 1995 and 2005 Guyana had 1005 newly registered businesses,

${ }^{1}$ Kimberly Amadeo, WTO Members, Categories, and Benefits. Three Reasons Why WTO Membership Is So Important. Updated July 10, 2018.

${ }^{2}$ UNODC. Illicit Drug Markets in the Caribbean. many of which were shell companies. This rise was despite a decline in the population due to an increase in the mortality rate (increase in drug-related deaths) as well as mass migration to the US, Canada, the Caribbean and the UK. ${ }^{3}$

Figure 1 shows a decrease in population between the years of 1995 and $2005^{4}$, but during these ten years, the Guyana government had claimed an increase in trade, local businesses, and consumer spending. In addition, the unemployment rate was at its highest in 20 years because those working in the drug trade could not legally register themselves as employed. There was also a significant increase in housing purchases, an increase in the importation and sale of cars as well as the construction of new buildings, primarily for business.

Although there was a significant increase in registered businesses, there was no significant increase in exportable products. Although there was a lack of productivity Guyana's GDP rose year after year during this period, (see below Chart as provided by the World Bank).

The Table 1 shows the increase in cocaine seizure shortly after the signing and implementation of the WTO rules. ${ }^{5}$ This data corresponds with an increase in drug use in the US, Canada, and the EU during the same period. These three countries increased their exports of finished products to the nations in the chart by an average of $37 \%$. These underdeveloped nations had hoped to see an increase in productivity from the prospects of exporting more goods to Western countries at reduced tariffs. Instead, there was a decline because the products manufactured in the underdeveloped countries could not compete under the high-quality manufacturing standards laid out by Western

${ }^{3}$ Tim Merrill, ed. Guyana: A Country Study. Washington: GPO for the Library of Congress, 1992.

${ }^{4}$ Guyana Population. (2018-06-12).

${ }^{5}$ Supra. Pg. 17.

*Corresponding author: Paul L, Department of Law, Graduate School of Zhejiang University, China, Tel: +8615000311576; E-mail: Ipaul24@yahoo.com

Received August 29, 2018; Accepted September 11, 2018; Published September 18, 2018

Citation: Paul L (2018) Guyana should Re-Evaluate its WTO Membership. J Glob Econ 6: 306. doi: 10.4172/2375-4389.1000306

Copyright: (c) 2018 Paul L. This is an open-access article distributed under the terms of the Creative Commons Attribution License, which permits unrestricted use, distribution, and reproduction in any medium, provided the original author and source are credited. 


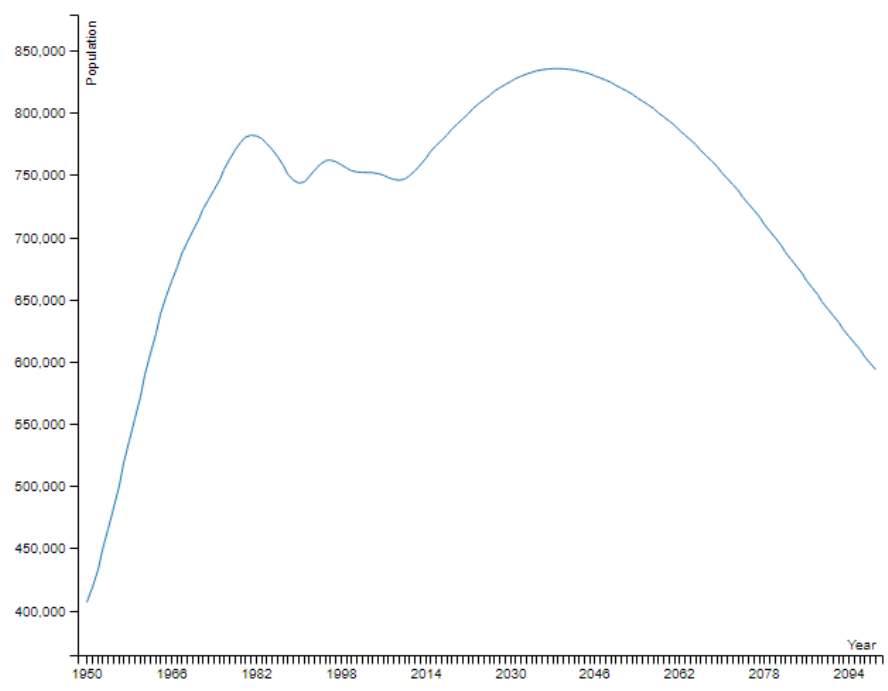

Figure 1: Decrease in population between the years of 1995 and 2005.

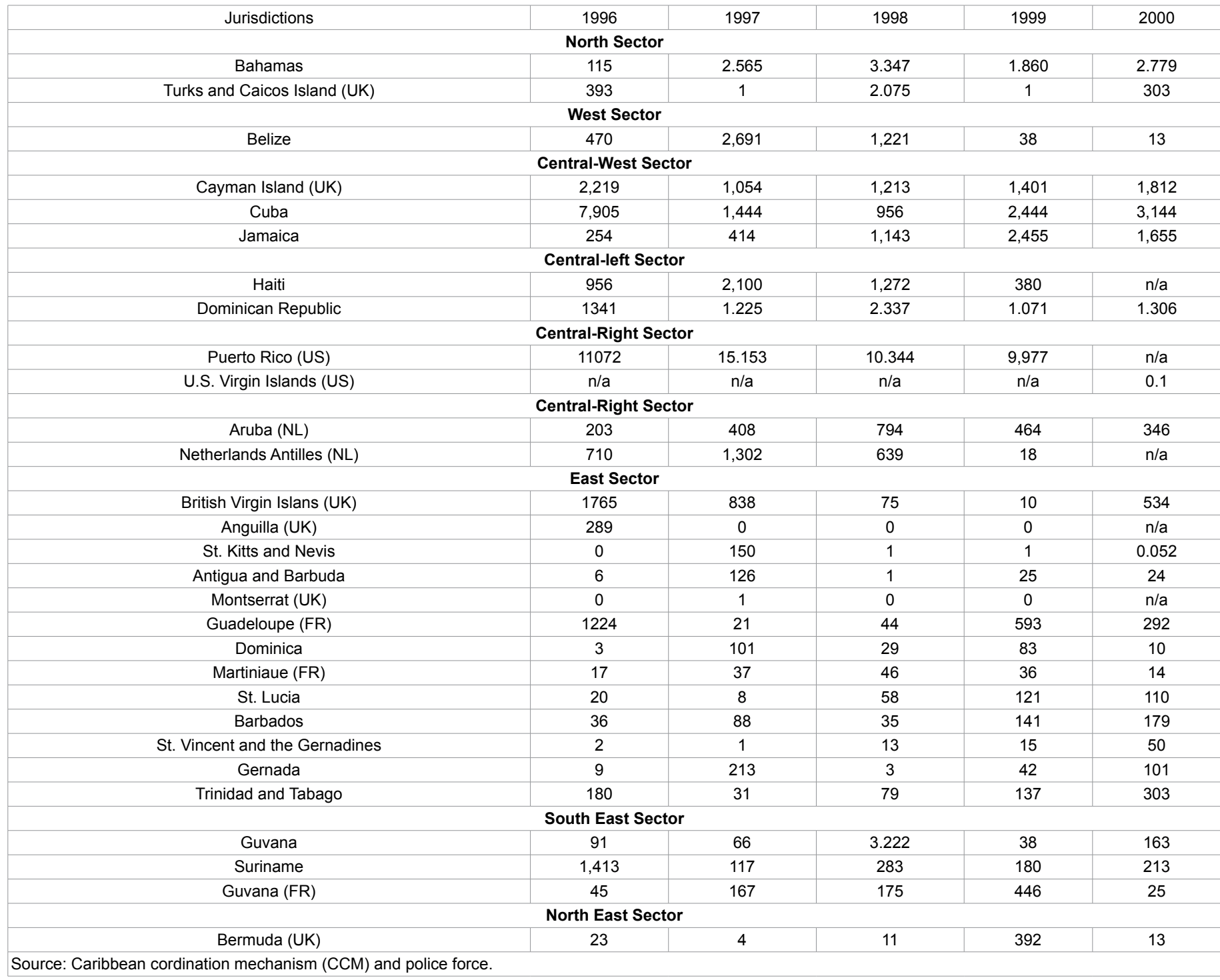

Table 1: Cocaine seizures in the Caribbean region, 1996-2000 (figures in kilos). 
countries [3,4]. To substitute for their loss, many business people turned to exporting drugs with their products to turn a profit.

Although there was a significant increase in registered businesses, there was no significant increase in exportable products. Although there was a lack of productivity Guyana's GDP rose year after year during this period, (see below Chart as provided by the World Bank).

Figure 2 shows a short background on Guyana may help to put things into perspective. ${ }^{6}$ Guyana, like many other post-colonial countries, found themselves in the new world order set out by the US and the UK after the Second World War. ${ }^{7}$ This new order saw the setting up of several neo-colonialist institutions that were designed to ease or facilitate trade between the developed countries and their ex-colonies. In 1945 the International Monetary Fund (IMF) was established to make it easier for nations to trade with each other and to create an avenue for developed countries to make international payments or loans while creating a bank-like revenue stream for its stakeholders. The World Bank was initially created at this time in 1944, called the International Bank for Reconstruction and Development. Both institutions were set up to facilitate payments from the US and the UK to developing countries that wanted loans for their post-colonial development projects [5]. In turn, the developing countries joined the General Agreement on Trade and Tariffs (GATT) in an attempt to bolster their export capabilities. Under GATT in the post-world war two reconstruction era, the developed countries needed resources from the under-developed countries to start their reconstruction work. In a framework of successive rounds of negotiations the developed countries set about strategically reducing tariffs on specifics items. All parties involved agreed to compromise based on the trading principle of non-discrimination and reciprocity. The developing countries at the time offered very few tariff concessions, so the developed countries were forced to bargain by offering concessions on products of interest to them. At the time, the products of most interests to developed countries were oil, mineral ore and bulk agricultural products such as coffee, sugar, and cocoa. The developing countries benefited from

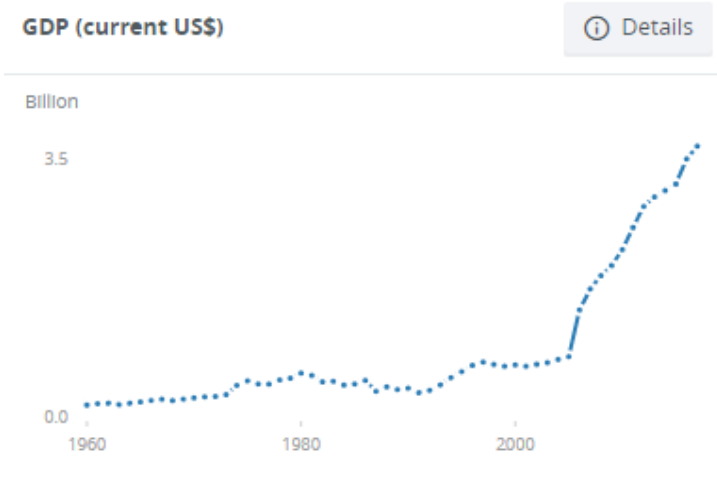

Figure 2: Guyana's GDP provided by the World Bank.

${ }^{6}$ The World Bank, IBRD-IDA. World Bank national accounts data, and OECD National Accounts data files. "GDP at purchaser's prices is the sum of gross value added by all resident producers in the economy plus any product taxes and minus any subsidies not included in the value of the products. It is calculated without making deductions for depreciation of fabricated assets or for depletion and degradation of natural resources. Data are in current U.S. dollars. Dollar figures for GDP are converted from domestic currencies using single year official exchange rates. For a few countries where the official exchange rate does not reflect the rate effectively applied to actual foreign exchange transactions, an alternative conversion factor is used."

${ }^{7}$ General Agreement on Trade and Tariffs. the tariff reduction on their most-favored-goods by using the mostfavored-nation clause set out in GATT and later adopted by the WTO. ${ }^{8}$ By the mid-1960s' the developed countries, the US being the primary actor, started to increase tariffs from lower to higher quality steadily and requested higher standard of fabrication. The increase inevitably had an adverse effect on developing countries which could not compete because as colonies they were not vested with the latest manufacturing technologies needed to ensure this higher level. Also, because of slavery and indentured labor in the colonies, there was a large body of unskilled low pay labor to do the work.

During the 1950 and 1960s, many countries across Africa, Central America, and the Caribbean became independent. These new Countries needed a steady cash flow to maintain their predominantly socialist agendas. The developed nations seeing the need being created in the new nations for large amounts of cash started a policy of importing the raw materials and returning the finished products under the already established rules. Because of the cheap products imported from developed countries, the productivity of the developing countries were stifled. This form of trade made legal by GATT created a type of dependency [7]. When Guyana became Independent in 1966 the then leader, Prime Minister Forbes Burnham implemented a Socialist type economic model where the state controlled all the major industries resulting in state-owned monopolies being formed which in turn stifled the creativity and innovation that comes as a result of competition, a by-product of capitalism. For almost two decades Guyana experienced regressive economic growth right alongside the continuous exportation of vast amounts of raw materials. The products Guyana exported were bauxite, gold, bulk sugar, rice, and fish. The finished products from these goods such as aluminum foil, chocolates and candies kept becoming more and more expensive and beyond the reach of ordinary Guyanese; many of whom may have worked in the same industries that produced and exported the raw materials. This trend was not isolated to Guyana; it was happening throughout the post-colonial world. In Africa and Central America, amidst rampant political mismanagement, countries found themselves increasing their raw materials export while global prices steadily declined under the pretext that the WTO rules had helped create a surplus in the market. ${ }^{9}$ In the 1980s the US had established its military and economic dominance over the world in a manner never seen before. While the US economy grew many underdeveloped countries became susceptible to rules and regulations imposed by the World Bank and the IMF institutions which made its decisions at the behest of the US Government and big businesses. ${ }^{10}$

After the invasion of Grenada, the US removed its then Prime Minister Bernard Coard who had allegedly assassinated the Marxist leader of the Government Maurice Bishop. Grenada under Maurice Bishop and Bernard Coard had a very leftist-Marxist style Government which aligned itself with Cuba and indirectly with the USSR. The invasion under the pretext of protecting American citizens saw the displacing of Coard from the Government and the installation of a Government favorable to the US and its pro-democracy policy. ${ }^{11}$ The actions by the US put all other underdeveloped countries on alert, meaning, the US can remove their leaders without any consequence [8]. When the US came calling for countries to sign on to the WTO in

${ }^{8}$ Bela Balassa, Trade between Developed and Developing Countries': The Decade Ahead. Pgs. 8-19.

${ }^{9}$ Supra.

${ }^{10}$ Erasmus Kersting and Christopher Kilby. Do Domestic Politics Shape US Influence on the World Bank. July 11, 2016.

${ }^{11}$ The United States invades Grenada. 2009. 
1995 many underdeveloped countries towed the line and did as was advised without evaluating the impact of GATT and how any negative impact from GATT can be carried over to the WTO.

There are a number of other reasons why Guyana and other small, underdeveloped countries should leave the WTO.

The primary decision-making process of the WTO is undemocratic. ${ }^{12}$ Wealthy developed countries often use their power outside the halls of the WTO to influence the vote of countries that seek loans, support for illegitimate Governments and military support during times of war or impending war. For example, the Government of Guyana received 15 million dollars in loans from the IMF to rehabilitate the country's sugar industry although Europe at the time was heavily subsidizing their sugar industry and was reducing the amount of sugar bought from the colonies, same as the US. The loans were granted although there was clear evidence that the Government was engaged in systemic corruption and the sugar industry was no longer viable when compared to countries with much more advanced sugar industries like those in the US. It is also no coincidence that the local sugar and rice industry started to falter. After Guyana attained Independence in 1966, sugar was the primary agricultural export, but by the year 2000 the industry was laying off workers, closing factories and selling off land to wealthy drug dealers who wanted to build condos as a way to launder their money. Europe no longer bought Guyana's brown sugar, instead sent white beet sugar to Guyana. Many found the white sugar more favorable because it helped to maintain the color of their products such as cakes and pastries, drinks and sugar snacks resulting in less consumption of local sugar. The drop in exports and a reduction in local consumption were too much to bear. Hence the industry began to cripple.

The riff in the WTO was made evident at the Seattle Ministerial conference. The Conference which was held November 30 to December 3,1999 , failed to achieve anything partly because the underdeveloped countries were unhappy with the labor standards set by the developed countries in the international trade agreement. ${ }^{13}$ The developing countries were opposed to discussions on core labor standards that they believed put them at a disadvantage. It was argued that the developed countries had a protectionist interest in removing the comparative advantage of lower-wage countries. Many countries stated that the way to proceed was not to enforce labor standards through the WTO [9]. Countries believed that any sanctions for breach of the standards would limit the number of people employed in the factories, resulting in unemployment and further increase poverty in these nations. ${ }^{14}$

Other factors hindering the growth of developing and underdeveloped nations would also include the willful neglect of the developed WTO members to rewrite, clarify or abolish ambiguous rules on how trade agreements were concluded. These deliberate ambiguous rules give too much flexibility to developed nations on how tariff $s$ are set on their goods. For example, negotiations between African countries on their minerals and agricultural exports have seen tariffs on more than $90 \%$ of their trade reduced, resulting in a flood of cheap European goods. There was an increase in tariffs for specific goods such as agriculture products (finished products) and a decrease on tariffs on raw materials which the EU use to make the finished products and ship to African countries. ${ }^{15}$

${ }^{12}$ M. Khor, Corpwatch. November 9, 2001.

${ }^{13}$ Andrea Broughton, Seattle WTO talks fail. European Observatory of Working Life. ${ }^{14}$ Ibid.

${ }^{15}$ Kanelo Pitso. The Nature of the World Trade Organisation. The Global Economic Governance (GEG) Africa programme is a policy research and stakeholde engagement program to strengthen the influence of pro-poor African coalitions at global economic governance fora. October 21, 2014.
The WTO's inability and unwillingness to tackle agriculture subsidies in the EU and the US are one of the most significant contributors to the lack of sustainable agriculture in most post-colonial countries. Up until the 1950s, most non-western-countries were selfsufficient and agricultural products from what was then colonies of Europe were shipped to Europe to help maintain their economies and feed their people while they shifted from farming to industrialization. However, after the colonies became independent European countries saw the urgency in ensuring a safe, continuous and reliable food supply produced at home. Also, they realized that with their advanced technology and wealth of financing they could produce specific products at a much cheaper cost than the ex-colonies. By the late 1980s European countries collectively subsidized approximately one-third of their agriculture products, the subsidies were said to be about 10 billion Euros per year. ${ }^{16}$ The subsidies were a planned intervention by the EU Common Agricultural Policy committee. At the 10th WTO Ministerial Conference in Nairobi, the members voted to end the subsidies, but by that time the damage had already been done. Underdeveloped countries like Guyana had already become dependent on the cheap products imported from Europe and America. Chicken farmers and milk producers in Guyana had suffered the most.

Before the importation of EU milk and milk products, the average Guyanese bought milk from local farmers who visited daily to sell fresh cow's milk throughout the city and countryside [10]. The issue people had with the milk was that it had to be pasteurized and properly stored in a refrigerator. In the countryside, many people did not have electricity or refrigerators. When the cheap powdered milk hit the market in the early 1990s, it was welcomed by all because there was no need for pasteurization and cold storage. The local milk producers did not have the technology to make powdered milk, and there was no other industry, such as yogurt or cheese manufacturing to utilize the surplus of milk held by the farmers. One by one, farmers started herding cattle for meat production, thus, slowly killing the local milk industry. By the year 2000, there were no more than two medium scale milk producers, a decline from over 30 producers, a decade earlier. Chicken producers faced a similar issue since the bulk of Guyana's chicken feed was imported from the US during the 1970s into the 2000s. The subsidized low-quality feed prevented the feed industry from being economically viable enough to compete. Also, the chickens produced by local farmers were smaller in comparison to the chickens imported from the EU and the US because of the use of modern farming techniques, including the use of chemicals to induce growth. Over time Guyanese switched from eating local organic chicken to imported chicken because the imported chicken was much meatier and cheaper. Under pressure from the US Government, the Guyana Government lifted import duties on US chicken, a move that within five years killed the local chicken industry. ${ }^{17}$

Figure 3 shows the extent of the subsidies offered by the EU to their farmers. ${ }^{18}$ As you can see, by the time the WTO took action in

${ }^{16}$ Claran Moran. World Trade deal sees agricultural export subsidies banned December 22, 2015

${ }^{17}$ Guyana Lifts Duty on Imported Chicken. "National Communications Network of Guyana (NCN) reports the acting commerce and Industry Minister, Irfan Ali, saying that he has taken this step to combat the scarcity of the commodity on the local market. A noticeable and sweeping increase in the price for chicken has been recorded locally in recent weeks.

The Ministry of Commerce says the importers were granted a 50 percent waiver on duty instead of the 60 percent requested for permission to import one million pounds, over the next six months." http://www.thepoultrysite.com/processing/ news/18177/guyana-lifts-duty-on-imported-chicken/ Accessed July 16, 2018

${ }^{18}$ Source: OECD, PSE/CSE database, 2010 


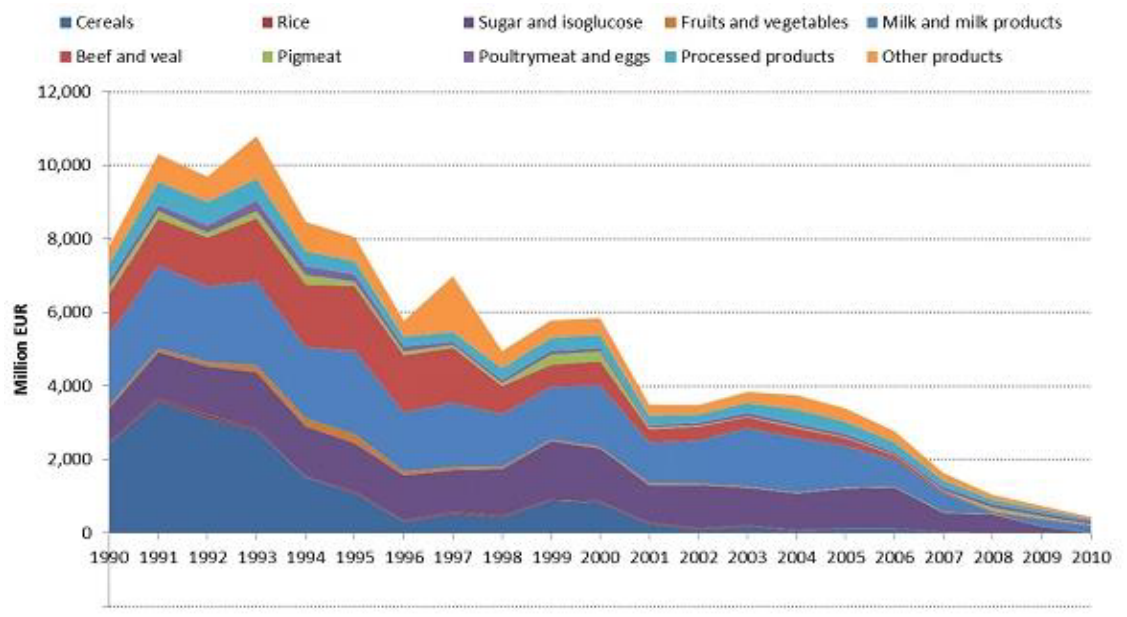

Figure 3: Extent of the subsidies offered by the EU to their farmers.

2010 at the Nairobi Conference the EU had already started to reduce it subsidies. This begs the question, whether the action of the WTO 2010 conference was predetermined or the US and EU allowed the abolishment of the subsidies because they no longer found a need for them [11]. The information on the graph also coincides with a period when foreign chicken started to saturate the market in Guyana because by the year 2000 most local producers had closed their farms, even the small home farmers with just a few chickens for personal consumption found it challenging to compete with the cheap imported chicken which was substantially meatier than local chicken.

The WTO has been beneficial to many nations, for example China, but it has had a destructive effect on the economy of others. It would be wrong to just blame the WTO for each of its member's economic woes. In many cases, there are some other factors at play resulting in bad deals under the WTO rules. For Guyana, quitting the WTO should be seriously considered since the economy and the Government that runs it is not strong enough or big enough to trade on the global market without falling victim to countries with a much more technologically advanced manufacturing sector. Currently, China has taken over from the US and the EU and is flooding the Guyana market with a host of products. The most prominent victim of Chinese manufacturing and trading superiority is Guyana's textile industry. The textile industry was once a source of pride for Guyanese because it provided material to produce all uniforms for schools and the armed forces as well as for local and export markets. Currently, the said textile mill is owned by a Chinese company that imports most of the raw materials from China to make fabric for the Guyana market. The cotton imported from China under WTO rules is much cheaper than the cotton grown on a much smaller scale in Guyana.

The current situation is reversible. There has been an increase in trade between Guyana and its Caribbean neighbors, primarily Trinidad and Tobago. The increase in trade is due to CARICOM. Under CARICOM the members can reduce tariffs making trade between them much more viable. CARICOM is a lucrative alternative because all the nations are in similar economic standing and none is significantly bigger or wealthier than the other. No nation in CARICOM holds an advantage similar to that of the European nations, Canada or the US. Another consideration, Guyana should sign individual Bilateral Investment Treaties (BIT) tailored to the needs of the economy [12]. The WTO should not be the main avenue of trade for any developing or underdeveloped country. Each country should adjust its trading strategy based on its long term and short term economic strategies. Charting their course away from the influence of the more powerful western nations is a much safer economic strategy.

\section{References}

1. Andrew Glass (2018) United States invades Grenada, Oct. 25, 1983.

2. http://www.crai.com/sites/default/files/publications/Developing_An Administrable_MFN_Enforcement_Policy_Salop_ScottMorton_Antitrust_ Spring_2013.pdf

3. Mattoo A, Subramanian A (2004) IMF Working Paper, Research Department The WTO and the Poorest Countries: The Stark Reality.

4. John JH (2006) The World Trade Organization: Structure of the Treaty and the Institution. Sovereignty, the WTO and Changing Fundamentals of International Law. Cambridge University Press.

5. LawTeacher (2013) Advantages and Disadvantages of World Trade Organization.

6. McCloure M (2011) Most Favored Nation Clauses. Wayback Machine, Kluwer Arbitration Blog.

7. Ozden C, Reinhardt E (2003) The Perversity of Preferences: The Generalized System of Preferences and Developing Country Trade Policies. World Bank Policy Research.

8. Ozden C, Reinhardt E (2018) The Perversity of Preferences: The Generalized System of Preferences and Developing Country Trade Policies. World Bank Policy Research. Working Paper No. 2955, Washington, US.

9. Steven CS, Morton FS (2013) Developing an Administrable MFN Enforcement Policy. Antitrust, 27: 1-5.

10. Understanding the WTO: the Organization. Members and Observers, 164 members since 29 July 2016 , with dates of WTO membership.

11. https://www.wto.org/english/thewto_e/whatis_e/tif_e/org6_e.htm.

12. Understanding (2018) the WTO: The Organization. Membership, alliances and bureaucracy. 